\title{
EVALUASI POLA PERESEPAN PADA PASIEN LANJUT USIA RAWAT JALAN DIABETES MELITUS TERHADAP KEJADIAN INAPPROPRIATE PRESCRIPTION DAN POTENTIALLY PRESCRIPTION OMISSION DI RSUD KRATON TAHUN 2019
}

\author{
EVALUATION OF PRESCRIPTION PATTERNS IN \\ ELDERLY OUTPATIENTS WITH DIABETES MELITUS \\ AGAINTS INAPPROPRIATE PRESCRIPTION AND \\ POTENTIALLY PRESCRIPTION OMISSION AT KRATON \\ HOSPITAL IN 2019
}

\author{
Selly Listiani, Ainun Muthoharoh, Lia Dwi Prafitri \\ Universitas Muhammadiyah Pekajagan Pekalongan \\ Jl. Ambokembang No. 08, Kec. Kedungwuni, Pekalongan, Jawa Tengah \\ Email: sellylistiani01@gmail.com (0877-3439-0903)
}

Submitted : 28 Februari 2021 Reviewed : 24 Maret 2021 Accepted : 29 Maret 2021

\begin{abstract}
ABSTRAK
Risiko Polifarmasi yang terjadi pada lanjut usia akan mengakibatkan terjadinya Inappropriate Prescription maupun Potentially Prescription Omission. STOPP START merupakan alat skrining yang digunakan untuk menghindari terjadinya penggunaan obat yang tidak tepat atau Inappropriate Prescription dan untuk menghindari potensi terjadinya obat- obatan yang dilalaikan dalam pengobatan atau Potentially Prescription Omission pada lanjut usia. Tujuan penelitian ini adalah untuk mengetahui prevalensi potensi terjadinya Inappropriate Prescription dan dan Potentially Prescription Omission dalam penggunaan obat-obatan menurut kriteria STOPP START pada pasien diabetes melitus lanjut usia di RSUD Kraton tahun 2019. Metode penelitian ini bersifat deskriptif secara restrospeksif terhadap rekam medis berdasarkan teknik systematic random sampling. Analisis data dengan menggunakan analisis univariat. Hasil dari penelitian ini menunjukan bahwa dari total samoel sebanyak 139 (100\%) terbagi $57(41 \%)$ laki-laki dan $82(59,0 \%)$ perempuan dengan rentang usia yang paling banyak $47(33,8 \%)$ dengan kejadian Inappropriate Prescription sebesar $82(59,0 \%)$ dan kejadian Potentially Prescription Omission sebesar $15(10,8 \%)$. Disarankan perlunya dilakukan peningkatan keilmuan pada tenaga kesehatan dalam memberikan terapi pengobatan kepada pasien lanjut usia.

Kata kunci : Diabetes Melitus, Ketepatan, Lanjut Usia, STOPP START
\end{abstract}

\section{ABSTRACT}

The risk of polypharmacy occurring in the elderly will result in Inappropiate Prescribing and Potentially Prescription Omission. STOPP START is a screening tool used to avoid inappropriate drug use or Inappropiate Prescribing and to avoid the potential for neglect in the treatment or Potentially Prescription Omission in the elderly. The aimed of this study was to find out the prevalence of potential Inappropiate Prescribing and Potentially Prescription Omission in the use of drugs according to STOPP START criteria in elderly outpatients of diabetes mellitus at Kraton Regional Public Hospital in 2019. This research method was retrospectively descriptive of medical records based on 
systematic random sampling technique. Analyze date using univariate analysis. The results of this study showed that the total sample was 139 (100\%) there are $57(41 \%)$ male and $82(59 \%)$ women with the most age range of 45-59 years with the most type of comorbid disease were hypertension at $47(33.8 \%)$ with the an Inappropriate Prescription inicidence of at $82(59.0 \%)$ and Potentially Prescription Omission incidence of $15(10.8 \%)$. It is recommended to increase the knowledge of health workes in providing drug theraphy to elderly patients.

Keywords: Accuracy, Elderly, Diabetes Mellitus, STOPP START

\section{Penulis Korespondensi :}

Selly Listiani

Universitas Muhammadiyah Pekajagan Pekalongan

Jl. Ambokembang No. 08, Kec. Kedungwuni, Pekalongan, Jawa Tengah

Email: sellylistiani01@gmail.com (0877-3439-0903)

\section{PENDAHULUAN}

Diabetes melitus (DM) adalah gangguan metabolisme yang terjadi pada organ pankreasyang ditandai dengan peningkatan kadar gula darah atau hiperglikemia akibat menurunnya jumlah insulin pada pankreas (Muthoharoh et al, 2020). Menurut Riskesdas 2018 prevalensi DM berdasarkan diagnosa dokter pasien lanjut usia yaitu pada kelompok umur $>45$ tahun sebanyak $16 \%$. Hasil tersebut menunjukan terjadi peningkatan penderita DM pada pasien lanjut usia per tahunnya. Pasien lanjut usia yang menderita DM mempunyai tingkat kematian tinggi yang lebih dini, kerusakan fungsional, dan penyakit penyerta, seperti hipertensi, penyakit jantug koroner, dan stroke dibanding pasien lanjut usia yang tidak menderita DM. Pada pasien lanjut usia yang menderita DM dapat berisiko lebih besar mengalami polifarmasi (Prasetyo, 2019).

Proses menua ditandai dengan terjadinya kemunduran sel-sel dan fungsi fisiologis yang berakibat pada lemahnya organ, kemunduran fisik, dan timbulnya berbagai penyakit degeneratif (P aras ari dan Lestari, 2015). Kondiri tersebut dan dengan beberapa kondisi medis yag menjadi penyebab pasien lanjut usia harus menerima beberapa obat lebih dari lima obat resep reguler, kondisi tersebut dikenal dengan polifarmasi (Jansen, 2016).

Tahun 2008 muncul alat evaluasi baru yaitu kriteria STOPP. Kriteria STOPP ini disusun berdasarkan keadaan fisiologis untuk mempermudah penggunaan duplikasi obat, interaksi obat- obat, dan interaksi obat-penyakit. Kriteria ini didesain secara khusus untuk digunakan bersama dengan kriteria START yang menekankan pada peresepan yang kurang tepat secara indikasi klinis, pengobatan berdasarkan bukti-bukti ilmiah. Oleh karena itu, kriteria STOPP START lebih luas cangkupan kriteria ketepatan pengobatannya dibandingkan dengan penggunaan kriteria Beers (O’Mahony et al, 2015).

Sebuah penelitian telah membandingkan kriteria STOPP START dengan kriteria Beers, kriteria Beers menunjukan kejadian IP sebesar 25\% sedangkan menggunakan kriteria STOPP START sebesar 48\% (Ubeda et al., 2012). Sedangkan, dalam penelitian lain mendeteksi adanya efek samping yang merugikan atau Adverse Drug Reaction (ADR) pada $\mathrm{p}$ asien lanjut usia menggunakan kriteria STOPP START 2,8 kali lebih sering daripada kriteria Beers (O’Mahony et al., 2015). Dari penelitian tersebut membuktikan bahwa kriteria STOPP START lebih sensitif terhadap kejadian Inappropriate Prescription maupun Potentially Prescription Omission dibandingkan dengan kriteria beers 2012.

Penelitian ini dilakukan di Instalasi rawat jalan RSUD Kraton Kabupaten Pekalongan dilakukan pada bulan Mei-Juni 2020. Tujuan penelitian ini adalah untuk mengetahui kejadian Inappropriate Prescription dan Potentially Prescription Omission di RSUD Kraton tahun 2019. 


\section{METODE PENELITIAN}

Penelitian ini merupakan jenis penelitian observasional dengan rancangan deskriptif yang bersifat retrospektif terhadap rekam medis pasien DM lanjut usia rawat jalan di RSUD Kraton Kabupaten Pekalongan tahun 2019.

\section{Alat dan Bahan}

Alat yang digunakan dalam penelitian ini adalah lembar pengumpulan data dan lembar panduan kriteria STOPP START. Bahan yang digunakan berupa catatan rekam medis pasien DM lanjut usia di RSUD Kraton tahun 2019.

\section{Jalannya Penelitian}

1. Penentuan Sampel Penelitian

Pengambilan sampel dilakukan dengan menggunakan teknik systematic random sampling sesuai dengan kriteria inklusi dan kriteria eksklusi yang telah ditetapkan. Adapun kriteria inklusi meliputi pasien DM rawat jalan yang berusia $>45$ tahun, pasien yang menerima lebih dari satu kali pengobatan yang terekam dalam 1 rekam medis, pasien DM dengan komplikasi atau tidak, pasien DM yang menerima obat lebih dari 5, dan rekam medis yang lengkap. Sedangkan kriteria eksklusi yaitu rekam medis yang sulit terbaca dan hilang. Dalam penelitian ini populasi pasien lanjut usia rawat jalan DM di RSUD Kraton tahun 2019 sebanyak 1.385, dimana untuk penentuan ukuran sampel penelitiannya adalah sebagai berikut:

$$
\begin{gathered}
\mathrm{n}= \\
10 \% \mathrm{x} \\
\mathrm{N} \\
\mathrm{n}=\frac{10}{100} \times \begin{array}{l}
1.385=138,5=139 \\
\text { sampel }
\end{array}
\end{gathered}
$$

Berdasarkan perhitungan sampel diatas, maka sampel diambil sebanyak 139 sampel yang memenuhi kriteria inklusi.

\section{Penelitian}

Penelitian dilakukan berdasarkan data rekam medis pasien DM lanjut usia rawat jalan tahun 2019, dimana data yang diambil dari rekam medis tersebut meliputi: nomor rekam medis, usia, jenis kelamin, obat yang digunakan, jumlah obat dan penyakit komplikasi

\section{Analisis Data}

Analisis data yang digunakan adalah analisis univariat untuk melihat frekuensi kejadian IP dan PPO pada pasien lanjut usia yang disajikan dalam bentuk persentase berupa tabel distribusi frekuensi relatif.

\section{HASIL DAN PEMBAHASAN}

Pada penelitian ini sampel yang diambil sebanyak 139 sampel yang sesuai dengan kriteria inklusi dan kriteria eksklusi yang telah ditetapkan. Pada bagian ini akan dibahas mengenai karakteristik pasien, pola peresepan pasien DM lanjut usia rawat jalan di RSUD Kraton tahun 2019 berdasarkan kriteria STOPP START, serta keterbatasan dalam penelitian.

\section{Karakteristik Penelitian}

\section{Jenis Kelamin}

Jenis kelamin terbagi menjadi 2 yaitu laki-laki dan perempuan. Berikut adalah perolehan data sejumlah pasien laki-laki dan perempuan dari sampel penelitian (lihat Tabel I) 
Tabel I. Karakteristik jenis kelamin pasien diabetes melitus lanjut usia di RSUD Kraton Tahun 2019

\begin{tabular}{clcc}
\hline No. & Jenis Kelamin & Jumlah (n) & Persentase (\%) \\
\hline 1. & Laki-laki & 57 & $41 \%$ \\
2. & Perempuan & 82 & $59 \%$ \\
\hline & Total & $\mathbf{1 3 9}$ & $\mathbf{1 0 0 \%}$ \\
\hline
\end{tabular}

Dilihat dari Tabel I bahwa lebih dari separuh (59\%) 82 pasien berjenis kelamin perempuan. Secara fisik pasien perempuan lebih berisiko menderita DM karena perempuan lebih rentan terjadinya peningkatan indeks masa tubuh yang lebih besar. Sindrom siklus bulanan (premenstrual syndrome), pasca-menopouse yang menyebabkan lemak tubuh perempuan menjadi lebih mudah terakumulasi akibat dari proses hormonal, dalam hal tersebut wanita lebih berisiko menderita DM (Trisnawati dan Setyorogo, 2013).

2. Umur

Kategori umur pasien DM lanjut usia digolongkan menurut WHO yaitu keompok usia pertengahan (midle age) usia 45-59 tahun, lanjut usia (elderly) usia 60-74 tahun, lanjut usia tua (old) usia 75-90 tahun, usia sangat tua (very old) usia 90 tahun.)

Tabel II. Karakteristik umur pasien

\begin{tabular}{|c|c|c|c|c|}
\hline \multirow{2}{*}{ No. } & \multicolumn{2}{|c|}{ Kategori Umur } & \multirow{2}{*}{$\begin{array}{c}\text { Jumlah } \\
\text { (n) }\end{array}$} & \multirow{2}{*}{$\begin{array}{c}\text { Persentase } \\
(\%)\end{array}$} \\
\hline & Kategori & Umur & & \\
\hline 1. & Usia pertengahan (midle age) & 45-59 tahun & 76 & $54,7 \%$ \\
\hline 2. & Lanjut usia (elderly) & $60-74$ tahun & 59 & $42,4 \%$ \\
\hline 3. & Lanjut usia tua (old) & 75-90 tahun & 4 & $2,9 \%$ \\
\hline 4. & Usia sangat tua (very old) & 90 tahun & 0 & 0 \\
\hline \multicolumn{3}{|c|}{ Total } & 139 & $100 \%$ \\
\hline
\end{tabular}

Berdasarkan Tabel II menunjukan bahwa pasien yang mengalami DM di RSUD Kraton tahun 2019 sebanyak (54,7\%) 76 pasien lanjut usia rentan umur 45-59 tahun. Seiring dengan bertambahnya usia dapat menyebabkan peningkatan risiko DM khususnya pada usia $>40$ tahun karena pada usia tersebut berada difase awal terjadinya peningkatan intoleransi glukosa. Adanya proses penuaan tersebut menyebabkan kemampuan sel $\beta$ pankreas dalam memproduksi insulin menurun (Trisnawati dan Setyorogo, 2013). Penelitian ini sama halnya dengan penelitian yang telah dilakukan oleh Trisnawati dan Setyorogo (2013) bahwa kelompok umur yang menderita DM >45 tahun lebih besar.

\section{Jumlah Obat}

Jumlah obat yang diterima pasien lanjut usia terbagi menjadi 2 yaitu paisen yang menerima obat $<5$ dan pasien yang menerima obat $\geq 5$. Karakteristik jumlah obat yang diterima pasien lanjut usia diabetes melitus rawat jalan di RSUD Kraton tahun 2019 dapatdilihat pada Tabel III

Tabel III. Karakteristik Jumlah Obat yang Diterima Pasien

\begin{tabular}{cccc}
\hline No. & Jumlah Obat yang Diresepkan & Jumlah (n) & Persentase (\%) \\
\hline 1. & $<5$ Obat & 16 & 11 \\
2. & $\geq 5$ Obat & 123 & 88 \\
\hline \multicolumn{2}{r}{ Total Pasien } & $\mathbf{1 3 9}$ & $\mathbf{1 0}$ \\
\hline
\end{tabular}

Berdasarkan Tabel III sebagian besar pasien DM di RSUD Kraton tahun 2019 menerima obat $\geq 5$ sejumlah $(88,5 \%) 123$ pasien. Hal tersebut menunjukkan bahwa pasien lanjut usia lebih rentan menerima obat lebih dari 5 atau biasa disebut polifarmasi. Penelitian yang telah dilakukan oleh Maher et al (2014) bahwa semakin bertambahnya usia 
pemberian obat lebih dari lima akan semakin meningkat 55\% sampai 59\% pada pasien rawat jalan. Sama halnya penelitian yang telah dilakukan oleh Julaiha (2018) mengemukakan bahwa sebanyak 72 pasien sebagian besar pasien atau lebih dari $60 \%$ pasien lanjut usia mendapatkan obat lebih dari 5 jenis atau lebih sedangkan sisanya menerima obat kurang dari 5.

\section{Penyakit Komplikasi}

Penyakit komplikasi pada pasien DM lanjut usia diketahui dari diagnosis medis dokter. Karakteristik penyakit komplikasi pada pasien DM lanjut usia rawat jalan di RSUD Kraton tahun 2019 dilihat pada Tabel IV

Tabel IV. Karakteristik Penyakit Komplikasi Pasien

\begin{tabular}{cccc}
\hline No. & Penyakit Komplikasi & Jumlah (n) & Persentase (\%) \\
\hline 1. & Tidak ada & 48 & $34,5 \%$ \\
2. & Ada & 91 & $65,5 \%$ \\
\hline \multicolumn{2}{c}{ Total Pasien } & $\mathbf{1 3 9}$ & $\mathbf{1 0 0 \%}$ \\
\hline
\end{tabular}

Berdasarkan Tabel IV menunjukkan bahwa pasien DM lanjut usia lebih banyak menderita penyakit komplikasi yaitu sebanyak 91 pasien $(65,5 \%)$. Penurunan fungsi organ yang terjadi pada pasien lanjut usia menyebabkan pasien lanjut usia lebih rentan menderita penyakit yang bersifat multi organ, dimana penyakit yang sering diderita pada pasien lanjut usia adalah hipertensi, DM, penyakit jantung coroner, stroke dan CHF (Dwi et al, 2017).

5. Pola Peresepan

Pola peresepan pada pasien DM lanjut usia diatur berdasarkan kriteria STOPP STARTdengan beberapa risiko yang berbeda-beda. Kriteria STOPP START merupakan alat skrinning yang digunakan untuk menghindari penggunaan obat yang tidak tepat atauinappropriate prescriotion dan untuk menghindari potensi adanya obat-obatan yangdilalaikan dalam peresepan atau potentially prescription omission pada pasien lanjut usia (Hopkins, 2011). Inappropriate Prescriotion dan Potentially Prescription Omission merupakan faktor terjadinya obat yang merugikan pada pengobatan pasien lanjut usia.

Tabel V. Distribusi Kejadian Inappropriate Prescription

\begin{tabular}{clcc}
\hline No. & \multicolumn{1}{c}{ Kejadian } & Total Kejadian (n) & Persentase (\%) \\
\hline 1. & Tidak terjadi IP & 57 & $41,0 \%$ \\
2. & Terjadi IP & 82 & $41,0 \%$ \\
\hline & Total & 139 & $100 \%$ \\
\hline
\end{tabular}

Dilihat dari Tabel 5 menunjukakan dari total sampel 139 sebanyak 83 pasien $(59,7 \%)$ mendapatkan kejadian Inappropriate Prescriotion. Penelitian yang telah dilakukan oleh Radiyati (2016) menunjukkan dari total lebih dari 100 pasien sebanyak 27,05\% mengalami penggunaan obat yang tidak tepat meningkat lebih dari 15\% (Rahmawati, 2015).

Tabel VI. Distribusi Kejadian Potentially Prescription Omission

\begin{tabular}{cccc}
\hline No. & \multicolumn{1}{c}{ Kejadian } & Total Kejadian $(\mathbf{n})$ & Persentase $(\%)$ \\
\hline 1. & Tidak terjadi PPO & 124 & $89,2 \%$ \\
2. & Terjadi PPO & 15 & $10,8 \%$ \\
\hline & Total & 139 & $100 \%$ \\
\hline
\end{tabular}

Dilihat dari Tabel 6 menunjukkan dari total sampel 139 sebanyak 15 pasien $(10,8 \%)$ mendapatkan kejadian Potentially Prescription Omission. Terjadinya Inappropriate Prescriotion dan Potentially Prescription Omission pada pasien lanjut usia disebabkan karena dalam penelitian ini banyak pasien DM lanjut usia yang menerima obat lebih 
dari lima. Menurut Syuaib et al (2016) bahwa penggunaan lebih dari 5 obat atau biasa disebut dengan polifarmasi merupakan faktor utama yang berhubungan dengan penggunaan PIM pada pasien lanjut usia. Hasil penelitian ini sesuai dengan penelitian yang dilakukan oleh Bhavya dan Torgal (2014) yang mengemukakan bahwa polifarmasi menjadi faktor prediktor utama yang berhubungan dengan kejadian PIMs $(p=0,024)$.

\begin{tabular}{|c|c|c|c|}
\hline No. & $\begin{array}{c}\text { Obat yang masuk kriteria dengan } \\
\text { kondisi tertentu }\end{array}$ & $\begin{array}{l}\text { Jumlah Resep } \\
\text { Pasien (n) }\end{array}$ & $\begin{array}{l}\text { Persentase } \\
\quad(\%)\end{array}$ \\
\hline 1. & Kriteria STOPP & & \\
\hline a. & 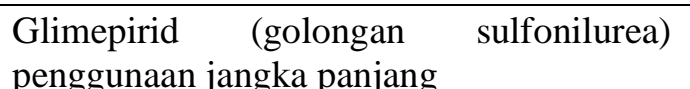 & 48 & 34,5 \\
\hline b. & $\begin{array}{l}\text { NSAID dengan pasien hipertensi sedang } \\
(160 / 100 \mathrm{mmHg}) \text { dan dengan penggunaan } \\
\text { jangka panjang untuk mengobati } \\
\text { steoarthritis }\end{array}$ & 3 & 2,2 \\
\hline c. & Duplikasi obat (NSAID-NSAID) & 2 & 1,4 \\
\hline d. & $\begin{array}{l}\text { Alprazolam (golongan benzodiazepin) } \\
\text { penggunaan jangka panjang }\end{array}$ & 3 & 2,2 \\
\hline e. & $\begin{array}{l}\text { Statin dengan tidak adanya sindrom } \\
\text { koroner/serebvaskular }\end{array}$ & 7 & 5,0 \\
\hline f. & $\begin{array}{l}\text { Diuretik loop dengan pasien inkontensia } \\
\text { urin }\end{array}$ & 2 & 1,4 \\
\hline g. & $\begin{array}{l}\text { Histamin-1 jika jatuh dalam } 3 \text { bulan } \\
\text { terakhir }\end{array}$ & 2 & 1,4 \\
\hline h. & $\begin{array}{l}\text { Metformin dengan pasien }(\text { GFR }<30 \\
\mathrm{ml} / \mathrm{min} / 1,73 \mathrm{~m})\end{array}$ & 1 & 0,7 \\
\hline 2. & Kriteria START & & \\
\hline a. & ACE Inhibitor pada pasien CHF & 8 & 5,8 \\
\hline b. & Clopidogrel dengan pasien stroke & 4 & 2,9 \\
\hline c. & $\begin{array}{l}\text { B-agonis (inhaled) dengan pasien } \\
\text { gangguan COPD/PPOK }\end{array}$ & 1 & 0,7 \\
\hline
\end{tabular}

Dilihat dari Tabel VII. Bahwa obat-obatan yang sering muncul dalam kejadian Inappropriate Prescriotion adalah penggunaan glimepirid sebanyak 48 pasien (34,5\%), disusul dengan penggunaan obat golongan statin sebanyak 7 (5,0\%), kemudian penggunaan golongan NSAID sebanyak $3(2,2 \%)$, penggunaan duplikat obat (NSAID-NSAID) sebanyak $2(1,4 \%)$, kemudian penggunaan obat golongan benzodiazepin sebanyak $3(2,2 \%)$, kemudian penggunaan obat golongan antihistamin generasi pertama sebanyak 2 $(1,4 \%)$, dan penggunaan obat metformin sebanyak 1 pasin $(0,7 \%)$.

Penggunaan golongan sulfonilurea aksi panjang pada pasien lanjut usia dapat meningkatkan risiko hipoglikemia berkepanjangan. Glimepirid merupakan obat golongan sulfonilurea aksi panjang yang sering digunakan. Obat golongan sulfonilurea aksi pendek seperti gliklazid atau glipizid mempunyai efek risiko hipoglikemia rendah daripada glimepirid atau gibenklamid (Dwi et al, 2017). Akan tetapi penggunaan glimepirid pada pasien ginjal kronik mempunyai profil keamanan yang lebih baik dibandingkan obat golongan sulfonilurea lainnya (Retta et al, 2018). Maka pengguaan gliklazid atau glipizid sangat disarankan untuk pasien lanjut usia.

Pada penelitian ini pemberian glimepirid secara terus menerus disebabkan karena dalam pemantauan atau monitoring kadar gula darah masih dalam rentang normal. Oleh karena itu, untuk penggunaan obat glimepirid atau golongan sulfonilurea aksi panjang pada pasien lanjut usia perlu dilakukannya monitoring kadar gula darah secara rutin untuk menghindari terjadinya hipoglikemia berkepanjangan. 
Pada penelitian ini kejadian Inappropriate Prescriotion yang sering terjadi adalah penggunaan NSAID sebanyak $3(2,2 \%)$ (lihat Tabel 7). Penggunaan NSAID pada pasien dengan hipertensi sedang dengan TD 160/100 mmHg-179-109 $\mathrm{mmHg}$ dapat berisiko aksaserbasi hipertensi. Mekanisme kerja obat NSAID dengan cara menghambat enzim siklo- oksigenase-1 dan siklo-oksigenase 2 (COX 1 DAN COX 2) sehingga dapat menurunkan produksi prostagladin (PGE2) dan prostasiklin (PG12) sebagai mediator inflamasi sehingga mengakibatkan terjadinya vasodilatasi. Selain itu, penghambatan produksi prostagladin ini dapat berefek pada retensi natrium. Dari mekanisme kerja obat tersebut yang menjadi akibat timbulnya beberapa komplikasi seperti hipertemsi, gangguan fungsi ginjal dan edema (Lovell dan Ernst, 2017).

Kemudian obat NSAID dengan penggunaan jangka panjang ( $>3$ bulan) untuk menghilangkan osteoarthritis dimana parasetamol belum dicoba seharusnya analgesik yang lebih sederhana lebih efektif. Asetaminofen (parasetamol) adalah obat pilihan pertama yang digunakan untuk tatalaksana terapi nyeri pada lanjut usia, tetapi penggunaannya sebaiknya harus diminimalisir karena efek sampingnya dapat merusaak hati (Barus, 2015). Penggunaan beberapa NSAID secara bersamaan tidak dianjurkan karena manfaat yang diperoleh tidak sebanding dengan efek sampingnya (Dwi et al, 2017).

Obat NSAID (non selektif) yang menghambat siklo-oksigenase (COX) 1 dan siklooksigenase (COX) 2 seperti diklofenak, mefenamat, dan ibuprofen yang mempunyai efek samping gangguan gastrointestinal. Dalam sebuah penelitian telah membuktikan bahwa obat NSAID non selektif maupun selektif dapat mengakibatkan peningkatan risiko penyakit kardiovaskuler (Barus, 2015). Pemberian NSAID pilihan utama adalah NSAID yang selektif yang bekerja menghambat siko-oksigenase COX-2 karena efek gastrointestinal yang minimal (Barus, 2015). Sehingga jika dibutuhkan, penggunaan NSAID pada pasien lanjut usia harus dimulai dari dosis kecil dan dinaikkan secara bertahap dan disesuaikan dengan toleransi pasien dan sasaran terapi.

Pada penelitian ini kejadian Inappropriate Prescriotion yang sering terjadi adalah penggunaan alprazolam golongan benzodiazepin (lihat Tabel VII) alprazolam merupakan obat golongan benzodiazepin yang memiliki aksi cepat yang dapat menyebabkan jatuh. Penggunaan obat golongan benzodiazepin pada pasien lanjut usia dapat menyebabkan peningkatan risiko kemunduran mental, jatuh, dan patah tulang (Sukmawati, 2016). Alprazolam dapat mengakibatkan terjadinya beberapa efek samping, salah satunya dapat mengakibatkan terjadinya ketergantungan (adiksi) fisik maupun psikis (Sepriani, 2014). Penggunaan awal obat-obat tersebut harus dimulai dengan dosis rendah dan kemudian dinaikkan perlahan sesuai kebutuhan (Dwi et al, 2017).

Penggunaan statin pada pasien DM berisiko terjadi peningkatan penyakit kardiovaskular tergantung pada lamanya penggunaan dan komplikasi DM, usia dan faktorrisiko yang menyertai. Penggunaan statin untuk semua pasien usia $>40$ tahun pada pasien DM tipe 1 dan 2 harus dipertimbangkan (BPOM, 2015).

Pada penelitian ini ditemukan pula kejadian Inappropriate Prescriotion pada penggunaan diuretik loop sebesar $2(1,4 \%)$ (lihat Tabel VII), pada penggunaan diuretik loop dengan pasien yang mengalami inkontensia urin bersamaan ketika menggunakan untuk terapi hipertensi dapat memperburuk inkontensia. Pada pasien lanjut usia baik wanita maupun laki-laki masalah inkontensia urin merupakan masalah yang umum terjadi ditandai dengan tidak mampu mengendalikan pengeluaran urin yang menyebabkan terganggunya kehidupan sosial, higuenus dan emosional sehingga nantinya akan berdampak pada masalah kesehatan (Amelia, 2020).

Pada penelitian ini ditemukan pula kejadian Inappropriate Prescriotion pada penggunaan antihistamin generasi pertama sebesar 2 (1,4\%) (lihat Tabel VII), penggunaan antihistamin generasi pertama pada pasien lanjut usia harus dihindari karena pada pasien lanjut usia obat-obat ini dapat melewati sawar darah-otak yang dapat menyebabkan efek samping pada susunan saraf pusat. Efek samping yang timbul sepeti kebingungan, mengantuk, kepala terasa melayang, gangguan fungsi kognitif, gangguan kemih, kosntipasi, gangguan ritme jantung, vasodilatasai pembuluh darah perifer, 
hipotensi postural/ortostatik, takikardia. Efek-efek tersebut yang dapat menyebabkan penggunaan histamin generasi pertama pada pasien lanjut usia jatuh dan terjadi perburukan hipertrofi prostat, dan penyakit jantung (Fia Fia et al, 2019).

Pada penelitian ini ditemukan pula kejadian Inappropriate Prescriotion pada satu penggunaan metformin (lihat Tabel VII) penggunan metformnin pada pasien dengan nilai GFR $<30 \mathrm{ml} / \mathrm{min} / 1,73 \mathrm{~m}$ dikontraindikasikan karena dapat berisiko asidosis laktat. Asidosis laktat terjadi jika konsentrasi plasma metformin $>20 \mathrm{mg} / \mathrm{L}$ yang dapat berakibat buruk jika mencapai $50 \mathrm{mg} / \mathrm{L}$. Metformin diekskresi $90 \%$ melalui ginjal dalam bentuk utuh sehingga berhubungan dengan GFR (Heaf, 2014).

Dilihat dari Tabel VII bahwa obat-obatan yang sering muncul dalam kejadian Potentially Prescription Omission atau obat-obatan yang sering dilalaikan pada peresepan diantaranya tidak diberikannya obat golongan ACE Inhibitor sebanyak 8 (5,8\%), kemudian tidak diberikannya obat clopidogrel pada pasien stroke sebanyak 4 $(2,9 \%)$, tidak diberikannya obat golongan $\beta$-agonis inhaled sebanyak $1(0,7 \%)$.

Pada penelitian ini kejadian pengobatan yang sering dilalaikan atau Potentially Prescription Omission. Kejadian Potentially Prescription Omission yang sering terjadi yaitu pada pasien CHF yang seharusnya menerima terapi inhibitor ACE. Menurut American College of Cardiology/American Heart Association (ACC/AHA) tahun 2013 penggunaan inhibitor ACE pada pasien gagal jantung sangat direkomendasikan, kecuali dengan penggunaan bersama $\beta$-bloker. Namun dengan penggunaan dosis yang sesuai dan dilakukan monitoring terhadap fungsi ginjal (Yancy et al, 2013).

Pada penelitian ini ditemukan pula kejadian pengobatan yang sering dilalaikan atau Potentially Prescription Omission. Kejadian Potentially Prescription Omission yang sering terjadi yaitu pada pasien stroke seharusnya diberikan terapi clopidogrel. Penggunaan clopidogrel pada pasien stroke sangat direkomendasikan baik stroke hemoragik maupun stroke non hemoragik (Julaiha, 2016). Clopidogrel merupakan obat golongan antiplatelet, antiplatelet merupakan obat yang mampu menghambat agregasi trombosit sehingga terhambatnya pembentukan trombus yang terdapat pada sistem arteri. Pemberian antiplatelet pada pasien stroke bermanfaat untuk mengurangi kekambuhan akibat penyumbatan dan kematian yang diakibatkan oleh pembuluh darah (Handayani et al, 2018).Kemudian kejadian obat yang dilalaikan atau Potentially Prescription Omission terjadi pada pasien dengan gangguan COPD yang seharusnya mendapatkan terapi $\beta$-agonis inhaled. Pemberian secara inhalasi efek samping yang diterima jauh lebih sedikit daripada pemberiaan secara oral. Sehingga pemberian inhalasi pada pasien lanjut usia sangat dianjurkan kecuali pada penderita yang tidak dapat atau tidak memungkinkan untuk mendapatkan terapi inhalasi (Nearimas, 2018).

\section{KETERBATASAN PENELITIAN}

Adapun Keterbatasan dalam penelitian ini adalah terdapat beberapa data yang tidak dapat ditemukan karena rekam medis tidak tertulis lengkap seperti diagnosis, pengobatan yang diberikan serta data pendukung berupa data laboratoriumnya. Dalam hal tersebut diatasi dengan memasukkan ke kriteria eksklusi. Keterbatasan dalam penelitian ini adalah karena penelitian ini merupakan penelitian retrospektif sehingga peneliti tidak dapat melihat kondisi klinis serta tidak dapat mengevaluasi kemungkinan timbulnya efek samping pada pasien DM lanjut usia.

\section{KESIMPULAN}

Kesimpulan yang dapat diambil dalam penelitian ini bahwa jumlah sampel yang diperoleh pada pasien lanjut usia diabetes melitus di RSUD Kraton tahun 2019 yaitu 57 (41\%) laki-laki dan $82(59 \%)$ perempuan dengan rentang usia yang paling banyak 45-59 tahun dengan jenis penyakit penyerta yang paling banyak hipertensi sebesar $47(33,8 \%)$ mengalami kejadian Inappropriate Prescriotion sebesar $82(59,0 \%)$ mengalami kejadian Potentially Prescription Omission 15 (10,8\%). 


\section{UCAPAN TERIMAKASIH}

Segala puja dan puji syukur alhamdulilah atas kehadirat Allah SWT atas segala nikmat dan karunia-Nya sehingga dapat terselesaikannya skripsi yang berjudul "Evaluasi Pola Peresepan Pada Pasien Lanjut Usia Rawat Jalan Diabetes Melitus Terhadap Kejadian Inappropriate Prescription dan Potentially Prescription Omission di RSUD Kraton Tahun 2019”. Selain itu penulis mengucapkan terimakasih kepada Civitas Akademika Universitas Muhammadiyah Pekajangan Pekalongan, Dosen Pembimbing, Dosen Penguji, RSUD Kraton Pekalongan, BAPPEDA, Kedua orang tua dan sahabat serta semua pihak yang telah banyak memberikan dukungan dan bantuan serta do'anya.

\section{DAFTAR PUSTAKA}

Muthoharoh, A., et al. 2020. Pola Pengobatan Antidiabetik Oral pada Pasien Diabetes Melitus Tipe 2 Rawat Jalan di RSUD Kraton Pekalongan. Pharmacon: Jurnal Farmasi Indonesia Edisi khusus (Rakerda-Seminar IAI Jateng) hal 29-36

Amelia, R. 2020. Prevalensi dan Faktor Inkontensia Urin Pada Lansia Panti Sosial Tuna Werdha (PSTW) Sumatera Barat. Health \& Medical Journal vol.11(1)

Bhavya, N.C., dan Torgal, S.S., 2014. Potentially Inappropriate Medication in Hospitalised Elderly Patients: a cross sectional study. International Journal of Basic \& Clinical Pharmacology. 3(1): 215-219

Badan Pengawas Obat dan Makanan (BPOM). 2015. Pusat Informasi Obat Nasional. Statin. Pionas.pom.go.id dikutip 30 Juni 2020

Barus, J. 2015. Penatalaksana Farmakologi Nyeri pada Lanjut Usia. CDK-226/vol.42 (3)

Dwi, A. S., Nila, D.L., Fitri, K. 2017. Evaluasi Ketidaktepatan Pemilihan Obat Berdasarkan Kriteria STOPP Pada Pasien Geriatri. Jurnal Farmasi Indonesia: Surakarta. 14(2). $182-190$

Fia Fia., et al. 2019. Penyuluhan Penatalaksanaan Alergi yang Memberikan Keluhan Kulit Gatal pada Lansia di Panti Werdha Salam Sejahtera. Jurnal Bakti Masyakat Indonesia vol. 2(2) hal 275-280

Handayani, D., dan Dominica, D. 2019. Gambaran Drug Related Problems (DRPs) pada Penatalaksanaan Pasien Stroke Hemoragik dan Stroke Non Hemoragik di RSUD Dr Yunus Bengkulu. Jurnal Farmasi dan Ilmu Kefarmasian Indonesia vol. $5(1)$

Heaf, J. 2014. Metformin in Chronic Kidney Disease: Time for a Rethink Acced June 01, 2020. $\mathrm{http://www.ncbi.nlm.nih.govl/pmc/articels/pmc4079480}$

Hopkins, G. B. S. C. 2011. STOPP START Criteria October 2011. Medico-Dental Pharmacy. 613-729-5151

Jansen, J. 2016. To Much Medicinein Older People? Deprescribing Throug Shared Decision Making. BMJ 2016;353 doi: http:/doi.org/10.1136/nmj.12893

Julaiha, S. 2018. Identifikasi Potentially Inappropriate Medication (PIMs) berdasarkan Kriteria STOPP START pada Pasien Geriatri Rawat Inap di RS Adven Bandar Lampung. Journal Analisis Kesehatan. 7(1). 657-665

Lovell, A dan Ernst, M. 2017. Drug Induces Hypertension: Focus on Mechanism and Management. Current Hypertention Report. Vol 19 hal 1-12

Maher, J.R. L., Hanlon, J.T., Hajjar, E.R. 2014. Clinical Consequences of Polypharmacy in Elderly. NIH-PA Author Manuscript. 13(1):1-2

Nearimas, T. 2018. Analisis Rasionalitas Penggunaan Obat pada Pasien Asma Rawat Inap di RSI Aisyiyah Malang Tahun 2016. Skripsi. Jawa Timur: Fakultas Kedokteran dan Ilmu- Ilmu Kesehatan UIN Maulana Malik Ibrahim Malang 
O'Mahony, D., et al 2015. STOPP/START Criteria for Potentially Inappropriate Prescribing in Older People: Version 2. Age and Ageing Oxford Journal. 44:213-218

Parasari, G. A. T., \& M. D. Lestari. 2015. Hubungan Dukungan Sosial Keluarga dengan Tingkat Depresi Pada Lansia di Kelurahan Sading. Journal Psikologi Udayana. 2(1): 68-77

Prasetyo, A. (2019) Tatalaksana Diabetes Melitus pada Pasien Geriatri. Pontianak: CDK-227 Vol. 46 (6): 420-422

Radiyanti., Rahmawati, F., Probosuseno. (2016). Peresepan Obat Tidak Tepat dan Adverse Drug Events pada Pasien Geriatri Rawat Inap di Rumah Sakit Umum. Jurnal Manajemen dan Pelayanan Farmasi vol. 6 (1) hal 47-54

Rahmawati, Y. R. 2015. Evaluasi Potensi Penggunaan Obat yang Tidak Tepat pada Peresepan Pasien Geriatri Rawat Jalan di RSD dr. Soebandi Jember Berdasarkan Beers Criteria. Skripsi. Universitas Jember

Retta, C.S., et al. 2018. Efikasi dan Keamanan Obat Diabetik Oral pada Pasien Diabetes Melitus Tipe 2 dengan Penyakit Ginjal Kronik. Jurnal Penyakit Dalam Indonesia vol. 5 (3) hal 150-155

Sukmawati., Kosman, R., Damayanti, I. 2016. Identifikasi Penggunaan Obat pada Pasien Hipertensi Usia Lanjut Dengan Beers Criteria di Instilasi Rawat Inap Rumah Sakit Ibnu Sinaf Makassar Periode Tahun 2012. As-Syifaa Vol. 08 (01) hal $52-58$

Syuaib, A. N. M., Darmawan, E., Mustofa. 2015. Penggunaan Potentially Prescribing Medication (PIMs) Pada Geriatri Rawat Inap Osteoarthritis di RS PKU Muhammadiyah Yogyakarta. Pharmaciana. 5(1): 77-84

Trisnawati, S. K., dan Setyorogo, S. 2013. Faktor Risiko Kejadian Diabetes Melitus Tipe II di Puskesmas Kecamatan Cengkareng Jakarta Barat Tahun 2012. Jurnal Ilmiah Kesehatan vol. 5 (1) hal 6-11

Yancy, C. W., et al. 2013. A Report of the American College of Cardiology Foundation/American Heart Associatron Task Force on Practice Guidline. 2013 ACCF/AHA Guidline for the Management of Heart Failure 